\title{
PENGEMBANGAN SISTEM INFORMASI KARYA ILMIAH MAHASISWA BERBASIS WEB DI PERPUSTAKAAN UNIVERSITAS PENDIDIKAN GANESHA
}

\author{
I Made Pendra Mahardika ${ }^{1}$, Ni Ketut Rai Yuli², Ni Kadek Etik Suparmini ${ }^{3}$ \\ 1,2,3 Unit Perpustakaan UNDIKSHA, \\ Singaraja, Indonesia
}
e-mail : pendramahardika77@gmail.com¹, niketutraiyuli@gmail.com², etikmini@yahoo.com³

\begin{abstract}
Abstrak
Tujuan penelitian ini untuk membuat rancangan bangun program sistem informasi karya ilmiah mahasiswa berbasis web dan implementasinya serta evaluasi program dengan ujicoba terbatas kepada pengguna dan penilaian dari pakar teknologi informasi. Metode penelitian yang digunakan adalah metode penelitian dan pengembangan (research and development) Paradigma yang digunakan dalam pengembangan perangkat lunak ini adalah paradigma prototyping. Pengembangan perangkat lunak dilakukan analisis untuk merumuskan sistem layanan online 24 jam pada koleksi karya ilmiah mahasiswa. Analisis kebutuhan menghasilkan rancang bangun yang kemudian diimplementasikan menjadi perangkat lunak sesuai spesifikasi yang ditentukan. Kinerja program tersebutdinilai oleh pakar teknologi informasi. Pemanfaatan program ini diuji melalui ujicoba terbatas kepada pengguna (mahasiswa). Hasil ujicoba sebagai berikut : 1) Pengembangan sistem informasi koleksi karya ilmiah mahasiswa berbasis web sudah sesuai dengan spesifikasi yang telah ditentukan sebagai sistem informasi berbasis web untuk dapat mengakses informasi koleksi karya ilmiah mahasiswa secara online dengan tampilan fulltext. 2)Indikator penilaian dari program ini seperti: kebenaran, keterluasan,efesiensi, portabilitas, verifikasi, modularitas, keterbacaan kinerja, kemudahan pemakaian, keramahan, dan kebergunaan mendapatkan kualifikasi baik, sedangkan ketegaran, keterpakaian ulang dan integritas mendapatkan kualifikasi cukup memadai yang perlu ditingkatkan lagi. 3) Secara umum dari hasil penilaian tersebut dapat dikatakan program tersebut sudah baik artinya sudah cukup layak untuk digunakan oleh pengguna sebagai sistem informasi koleksi karya ilmiah mahasiswa yang berbasis web.
\end{abstract}

Kata kunci : Sistem informasi,karya ilmiah mahasiswa, web.

\begin{abstract}
The purpose of this research was made software information system of the student's scientific works collection through web-based and implementation and was also validated by the experts in Information Technology and test its applicability to users. Research and development design was applied in this research through prototyping paradigm for software development. Development of software was done analysis for online 24 hours
\end{abstract}


service system to the student's scientific works collection. Need analysis was made design and was applied to software. the program was also validated by the experts in Information Technology and test its applicability to users. The trial results shows that: (1) the developed software has fullfiled the specification needed in access information of the student's scientific works collection according to online with fulltext. (2) The assessment indicators of the program include: truth, wideness, efficiency, portability, verification, modularity and readability, performance, ease of use, friendliness, and the usefulness gain good qualification, while the Robustness, reusability and integrity which are assessed by the experts gain sufficient qualifications that needs to be improved; (3) the results of these assessments can be concluded that the program is good, especially to fasicilate the user in order to the informations system the collection of student's scientific work.

Keywords: information systems, software, collection of scientific papers.

\section{PENDAHULUAN}

Perpustakaan bertujuan memberikan layanan kepada pemustaka, meningkatkan kegemaran membaca, serta memperluas wawasan dan pengetahuan untuk mencerdaskan kehidupan bangsa untuk mendukung hal tersebut perpustakaan sebagai institusi pengelola koleksi karya tulis, karya cetak, dan/atau karya rekam harus dilakukan secara professional. koleksi perpustakaan diseleksi, diolah, disimpan, dilayankan, dan dikembangkan sesuai dengan kepentingan pemustaka dengan memperhatikan perkembangan teknologi informasi dan komunikasi (pasal 4 UU 43 tahun 2007 tentang perpustakaan).

Koleksi karya ilmiah mahasiswa pada Perpustakaan Universitas Pendidikan Ganesha yang terdiri dari koleksi tesis, skripsi, dan tugas akhir sudah dikelola dengan sistem yang baku sesuai dengan aturan perpustakaan dan menerapkan teknologi informasi. Walaupun layanan karya ilmiah mahasiswa di Perpustakaan Unversitas Pendidikan Ganesha sudah menerapkan sistem otomasi tapi masih ditemukan beberapa permasalahan. Kesulitan menemukan koleksi di lokasi penyimpanan (rak koleksi) walaupun di katalog tercantum. Hal ini disebabkan oleh perilaku pengguna yang menyembunyikan koleksi di lokasi penyimpanan (rak koleksi) yang tidak sesuai, sebagai contoh kasus ini terungkap dari koleksi tahun 2014 yang ditemukan oleh pustakawan (petugas perpustakaan) di rak tahun 2012.

Jumlah koleksi yang disimpan di rak koleksi hanya 1 eksemplar sehingga membatasi akses pemanfaatan satu koleksi untuk satu orang pengguna pada waktu yang sama. Ditinjau dari waktu, buka layanan karya ilmiah mahasiswa Perpustakaan Undiksha dibuka hari senin sampai kamis pukul 08.00-19.00 wita dan jumat pukul 09.00-19.00 wita. Waktu yang disediakan dalam layanan tersebut masih dirasakan kurang memadai oleh pengguna. Kasus ini terungkap dari survei yang dilakukan kepada 100 orang pengguna (mahasiswa) mengatakan bahwa 89 orang mahasiswa menginginkan waktu layanan yang lebih banyak sedangkan sisanya sebanyak 11 orang mahasiswa mengatakan sudah cukup waktu layanan koleksi karya ilmiah mahasiswa. Hal ini berarti $89 \%$ pengguna (mahasiswa) menginginkan waktu layanan yang lebih banyak $11 \%$ orang pengguna mengatakan waktu layanan 
sudah cukup. Idealnya perpustakaan dibuka layanan 24 jam sehari. Hal ini dapat berimplikasi pada kepuasan pengguna dimana waktu buka layanan yang tidak sesuai dengan harapan pengguna sehingga dapat menghambat penyelesaian tugas akademik mahasiswa. Paradigma teknologi informasi bahwa penerapan teknologi informasi digunakan untuk memberikan layanan yang lebih efektif dan meningkatkan efesiensi kerja (Corbin,1985 dan Rowley,1980). Penerapan teknologi sebagai solusi digunakan mengingat adanya proses transformasi kultural menuju masyarakat informasi (Hamad, 2010:35-43). Hal serupa juga diungkapkan oleh Welnadi (2010:8-15), bahwa budaya informasi terus berkembang mengikuti perkembangan teknologi informasi. Ini bisa terlihat dari paradigma perkembangan penyampaian informasi dari budaya informasi konvensional menuju budaya informasi virtual / maya melalui internet. Tujuannya adalah agar informasi tersebut akurat, relevan dan tepat waktu seperti yang diungkapkan oleh Burch dan Grudnitski (dalam Pendra, 2013:12). Berdasarkan kajian permasalahan, paradigma teknologi informasi, peluang internet yang sudah disediakaan oleh lembaga Undiksha dan program bebas pustaka online yang didalamnya terdapat modul upload softcopy file hasil karya ilmiah mahasiswa yang merupakan hasil penelitian penulis yang pertama tahun 2013. Kemudian dilanjutkan ke program sistem otomasi pengolahan koleksi karya ilmiah mahasiswa yang juga merupakan hasil penelitian penulis selanjutnya tahun 2014, maka penulis ingin melanjutkan ketahapan berikutnya untuk pengembangan layanan karya ilmiah mahasiswa Perpustakaan Undiksha dalam rangka meningkatkan kualitas layanan perpustakaan dengan menerapkan teknologi informasi (internet), dimana teknologi ini mudah diakses dan bersifat online full time dengan memberikan layanan online 24 jam yang merupakan transformasi pelayanan yang lebih baik sehingga mampu meningkatkan kepuasan pengguna (Pendra, 2014:342). Dengan demikian penulis mengajukan penelitian tahap selanjutnya tentang pengembangan sistem informasi koleksi karya ilmiah mahasiswa berbasis web di perpustakaan Undiksha Singaraja.

Beberapa penelitian lainnya tentang sistem informasi berbasis web yang identik dengan penelitian ini telah dilakukan oleh beberapa peneliti dengan kasus yang berbeda-beda. Setemen dkk,(2012) telah mengembangkan sistem pengarsipan karya ilmiah mahasiswa dan dosen berbasis web yang mengakomodasi pengelolaan karya akademik mahasiswa dan dosen sebagai rujukan mahasiswa dan dosen melakukan penelitian. Daulay (2012) telah mengembangkan model penelusuran dokumen aktivitas tanya jawab mahasiswa dan tutor dalam tutorial online (tuton) melalui sistem $F A Q$, seluruh dokumen tanya jawab dikumpulkan dalam aplikasi FAQ agar dapat diakses mahasiswa dalam bentuk online dalam format HTML. Irmayanti (2011) telah melakukan penelitian pengembangan perpustakaan digital puslata UT dalam mendukung sistem belajar jarak jauh. Tujuan penelitian ini untuk menyajikan informasi tentang pengembangan dan pemanfaatan perpustakaan digital Puslata UT dalam mendukung sistem belajar jarak jauh. Azizah dan Fery Siswadi (2011) melakukan penelitian Pengembangan ElibISIS. Tujuan penelitian ini adalah untuk membangun ElibISIS yang merupakan Electronic Library berbasis data CDS/ISIS, dibuat untuk menyajikan database koleksi 
Perpustakaan Pusat IPB dan Perpustakaan Fakultas yang ada di lingkungan IPB, agar dapat diakses melalui jaringan intranet maupun internet.

Tujuan yang ingin dicapai dalam penelitian ini adalah untuk mengetahui (1) Pengembangan sistem informasi karya ilmiah berbasis web yang meliputi rancang bangun dan implementasinya, (2) Kualitas/kinerja pengembangan sistem informasi karya ilmiah mahasiswa berbasis web dengan ujicoba terbatas kepada pengguna (mahasiswa) dan penilaian dari pakar teknologi informasi.

\section{METODE}

Penelitian ini merupakan penelitian pengembangan perangkat lunak. Pada penelitian ini ada dua tahap utama, yaitu: pengembangan dan uji coba (evaluasi) perangkat lunak. Tahapan penelitian ini adalah sebagai berikut.

Penelitian ini merupakan pengembangan perangkat lunak, dengan sasaran akhir yang diharapkan adalah terciptanya sebuah perangkat lunak (software) sesuai dengan spesifikasi yang ditetapkan. Oleh karena itu, metode yang digunakan mengikuti paradigma dalam pengembangan perangkat lunak yaitu paradigma prototyping. Paradigma ini dipilih karena pengembangan perangkat lunak dapat dikerjakan secara terpadu antara pustakawan dan pakar teknologi informasi.

Pada pengembangan perangkat lunak dengan paradigma prototyping, memungkinkan pengembang untuk membentuk model perangkat lunak (prototipe) yang diharapkan. Prototipe tersebut selanjutnya dievaluasi dan diperbaiki bersama-sama apabila sudah dianggap layak, maka perangkat lunak tersebut langsung diproduksi sedangkan kalau masih ada kekurangan, maka dilakukan perbaikan. Kelebihan paradigma ini adalah terjadi kesesuaian antara permintaan pemakai dengan rancangan yang dibuat oleh pengembang dengan lebih cepat. Urutan langkah pada paradigma prototyping diilustrasikan dalam gambar di bawah ini.

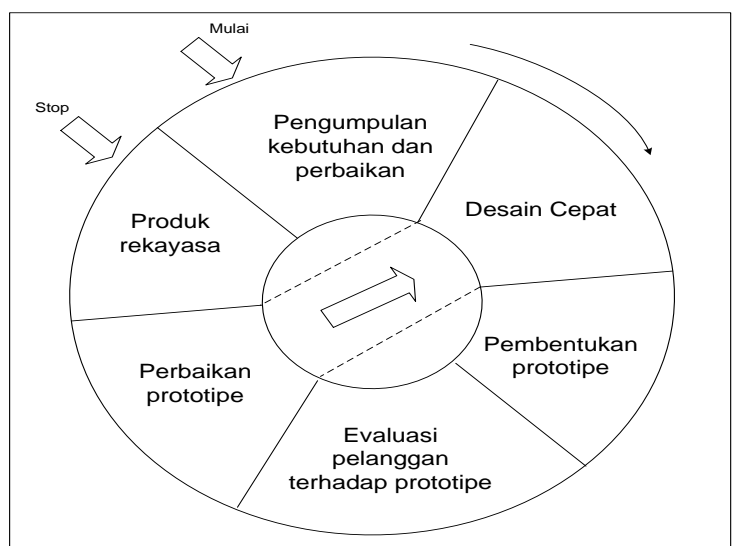

Gambar 1. Diagram Pengembangan Perangkat Lunak 
Pertama yang dilakukan adalah analisis desain sistem informasi karya ilmiah mahasiswa dilakukan oleh pustakawan. Setelah proses analisis desain pengolahan koleksi karya ilmiah mahasiswa sudah selesai, maka dilanjutkan pada tahap penyusunan rancang bangun sistem informasi karya ilmiah mahasiswa berbasis web. Rancang bangun yang dikembangkan mencakup: (a) diagram use-case; (b) Rancangan database dengan ERD (Entity Relationship Diagram); (c) Diagram aktivitas

Rancang bangun yang tersusun kemudian diimplementasikan menjadi perangkat lunak sistem informasi karya ilmiah mahasiswa berbasis web. Komponen-komponen sistem informasi karya ilmiah mahasiswa berbasis web diimplementasikan mencakup : (a) antarmuka program (interface); (b) koneksi (link), dan (c) fitur-fitur layanan.

Komponen-komponen tersebut kemudian diintegrasikan menjadi produk akhir perangkat lunak sistem informasi karya ilmiah mahasiswa berbasis web. Perangkat lunak sistem informasi karya ilmiah mahasiswa berbasis web yang sudah jadi kemudian dievaluasi. Evaluasi dilakukan oleh pakar dan pengguna. Pembuatan sistem informasi karya ilmiah mahasiswa berbasis web melibatkan dua bidang keahlian yaitu keahlian di bidang perpustakaan (pustakawan) dan keahlian di bidang teknologi informasi. Dengan demikian pakar yang dilibatkan dalam evaluasi adalah pakar teknologi informasi dan pustakawan. Berdasarkan evaluasi oleh pakar dan pengguna, dilakukan revisi terhadap sistem sistem informasi karya ilmiah mahasiswa berbasis web. Evaluasi dan revisi dilakukan berulang-ulang sampai sistem informasi karya ilmiah mahasiswa berbasis web memenuhi kreteria atau kebutuhan pengguna dan sudah dinyatakan layak untuk diproduksi. Revisi dapat dilakukan mulai dari rancang bangun dan seterusnya hingga implementasi atau revisi pada implementasi saja, tergantung kesalahan yang terjadi, apabila kesalahan hanya terjadi pada sintaks pemrograman maka revisi hanya dilakukan pada implementasi. Apabila kesalahan terjadi pada desain maka perbaikan dilakukan mulai rancang bangun dan dilanjutkan dengan revisi pada implementasi.

Perangkat lunak sistem informasi karya ilmiah mahasiswa berbasis web yang sudah dikembangkan kemudian diintegrasikan dengan program bebas pustaka online yang ada di web UNDIKSHA dengan alamat http: www. Undiksha.ac.id. dan program sistem otomasi pengolahan koleksi karya ilmiah mahasiswa. File softcopy karya ilmiah mahasiswa yang diupload oleh mahasiswa pada program layanan bebas pustaka online pada modul simpan karya ilmiah mahasiswa. Pada modul tersebut, mahasiswa mengisi judul, nama, no induk mahasiswa, jurusan, dan upload softcopy hasil karya ilmiah mahasiswa. Data tersebut disimpan di server perpustakaan, kemudian diintegrasikan ke perangkat lunak sistem otomasi pengolahan koleksi karya ilmiah mahasiswa pada modul penelusuran informasi koleksi yang disebut OPAC dan akhirnya diintegrasikan ke perangkat lunak sistem informasi karya ilmiah mahasiswa.

Selanjutnya, perangkat lunak tersebut diujicoba oleh pakar dan pengguna sistem. Pakar melakukan penilaian perangkat lunak dengan mengobservasi bagian internal program dan mencoba menjalankannya. Beberapa indikator penilaian terhadap perangkat lunak yang dihasilkan menurut Candiasa 
(2012:66) adalah kebenaran atau ketepatan operasional sistem, kemampuan program untuk mengantisipasi kondisi abnormal dalam menjalankan fungsinya, kemudahan untuk mengadaptasikan program bila terjadi perubahan spesifikasi, keberadaan program untuk bisa dipergunakan kembali baik sebagian atau seluruhnya untuk aplikasi lain, efisiensi terhadap sumber daya, kemudahan program ditransfer ke perangkat keras yang berbeda, kemudahan untuk menelusuri kegagalan program dan validasi, kemampuan program memproteksi diri dari penggunaan dan modifikasi illegal, kejelasan pengaturan modul-modul dalam program, dan keterbacaan program oleh orang lain selain programmer.

Setelah mengobservasi bagian internal sistem informasi karya ilmiah mahasiswa berbasis web dan mengobservasi hasil eksekusi program, pakar melakukan penilaian menggunakan instrumen. Rekomendasi dari pakar dari hasil ujicoba ditindaklanjuti dengan proses perbaikan perangkat lunak. Setelah dilakukan perbaikan perangkat lunak, selanjutnya dilakukan ujicoba terhadap beberapa mahasiswa Undiksha. Indikatorindikator penilaian yang digunakan antara lain kinerja perangkat lunak, kemudahan pemakaian dan pengoperasian perangkat lunak, keramahan perangkat lunak untuk memberi petunjuk pada pengguna, dan kebermanfaatan perangkat lunak bagi pengguna.

\section{HASIL DAN PEMBAHASAN}

Pengembangan sistem informasi karya ilmiah mahasiswa berbasis web ini dirancang untuk pengguna yang ingin melakukan penelusuran informasi koleksi karya ilmiah mahasiswa.melalui web Undiksha. Program terintegrasi dengan program layanan bebas pustaka online (hasil penelitian penulis sebelumnya) pada upload file simpan karya ilmiah mahasiswa. Data yang diupload oleh mahasiswa tersebut sebagai tahapan input kemudian diproses atau diolah oleh program sehingga mendapatkan output berupa tampilan fullteks koleksi karya ilmiah mahasiswa Undiksha. Sebagai berikut gambaran rancangan sistem, rancangan database dengan menggunakan $E R D$ (Entity relationship diagram) dan rancangan interface dari program pengembangan sistem informasi karya ilmiah mahasiswa berbasis web :

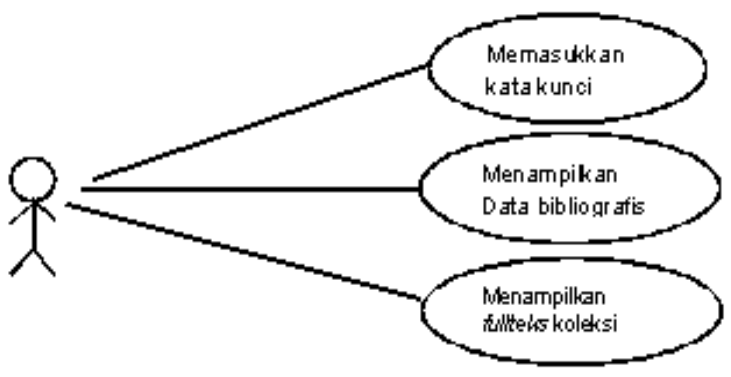

Gambar 2. Rancangan Sistem 


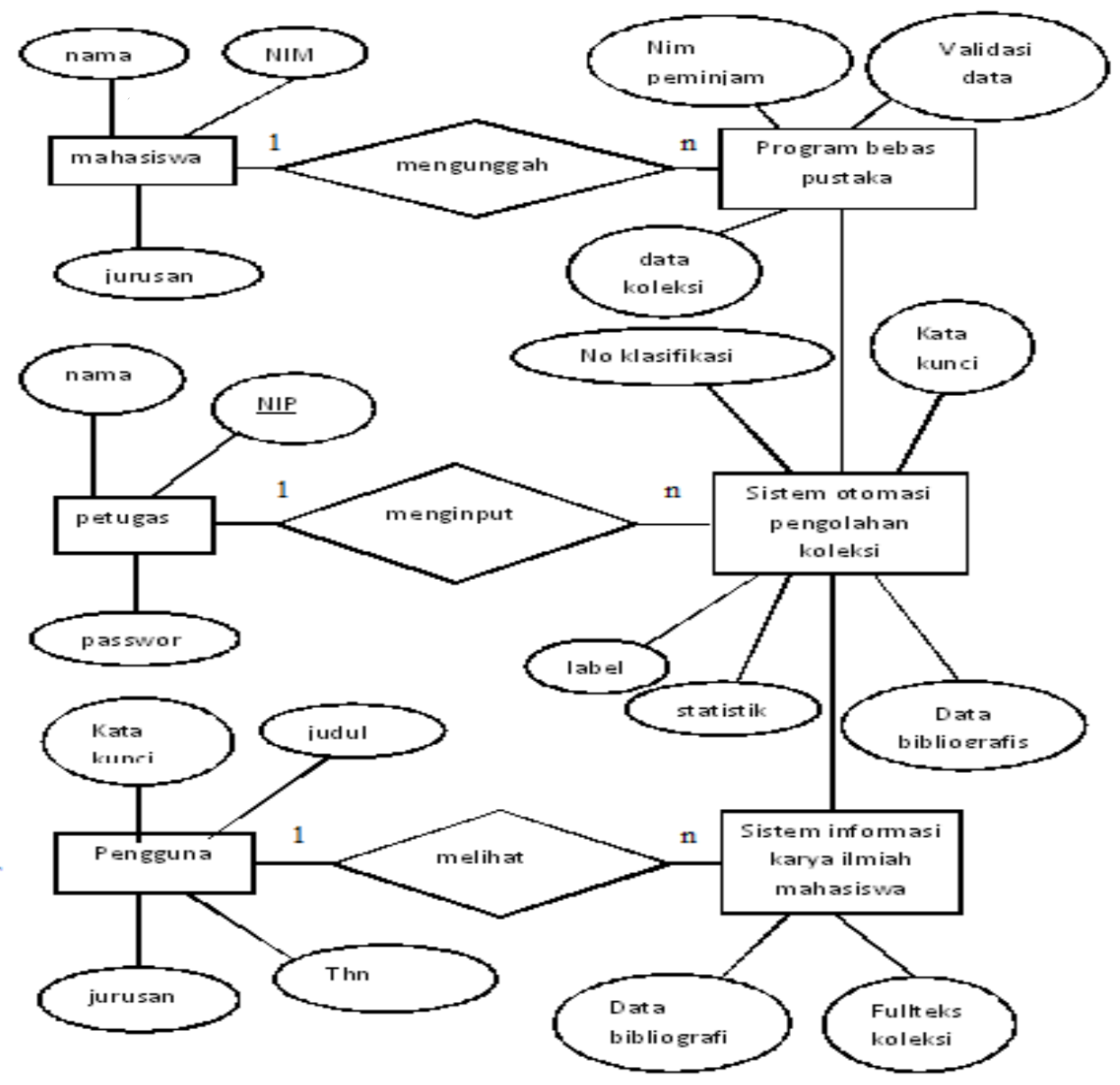

Gambar 3. Rancangan database dengan menggunakan ERD

Tampilan interface program sistem informasi karya ilmiah mahasiswa berbasis web. Pada tampilan berikut ini akan disuguhkan halaman depan program. 


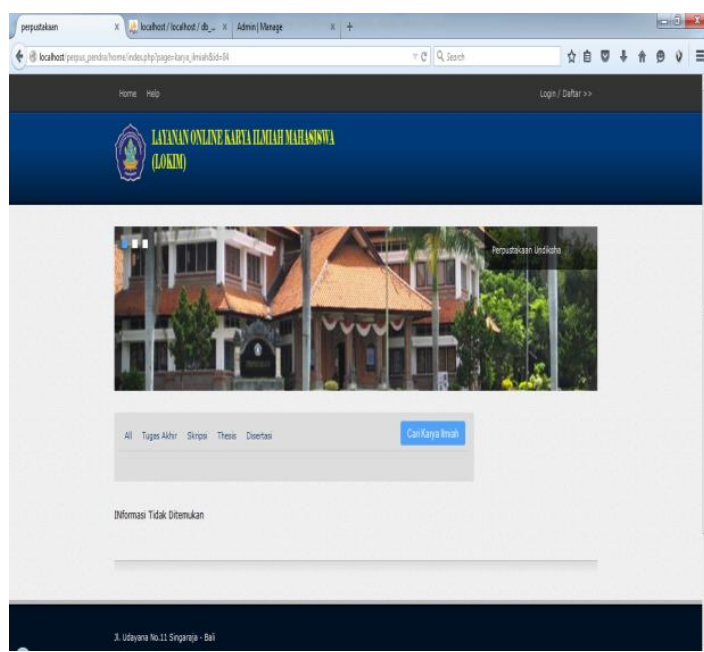

Gambar 4. Halaman depan program

Pada halaman depan program yang ditampilkan beberapa ikon koleksi karya ilmiah mahasiswa yang dimiliki oleh Perpustakaan Undiksha yang terdiri dari tugas akhir, skripsi dan tesis. Pada
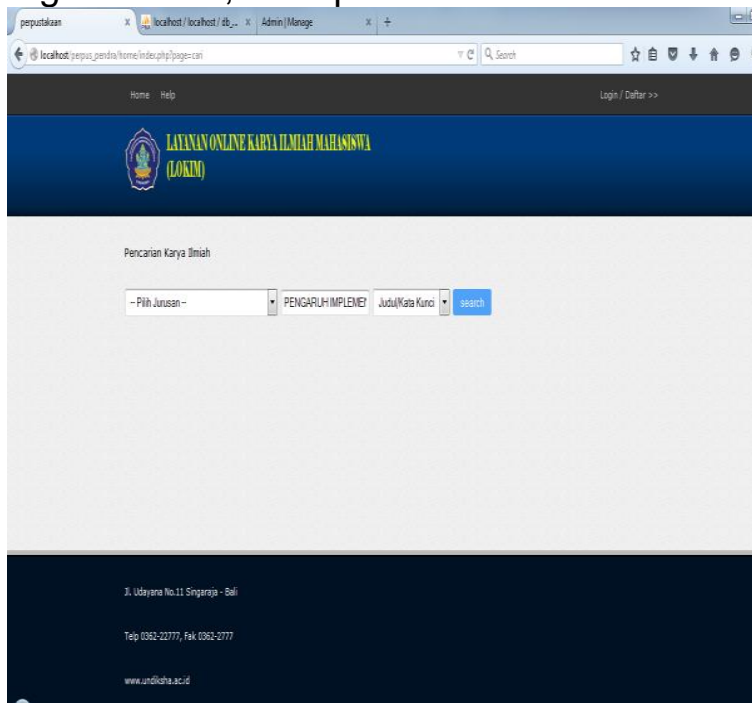

Gambar 6. Pencarian karya ilmiah mahasiswa berdasarkan judul atau kata kunci

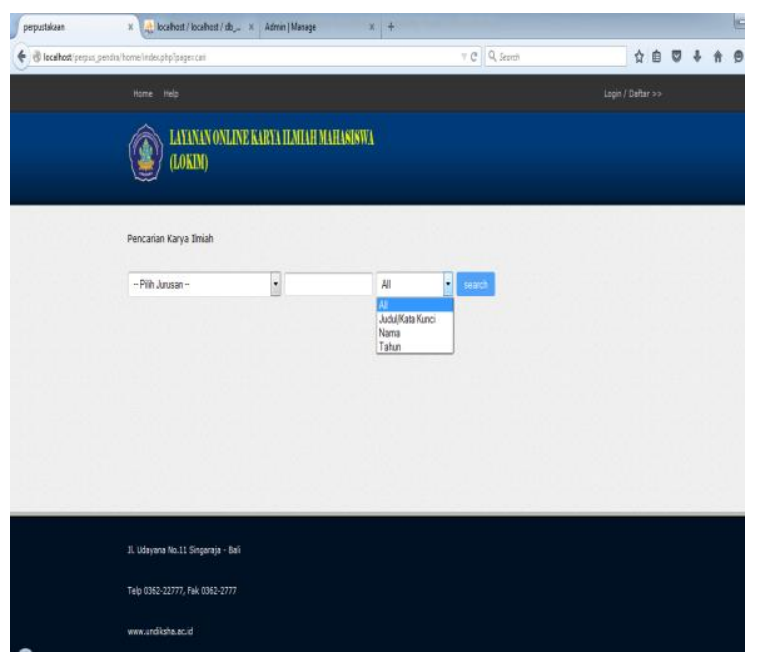

Gambar 5. Pencarian karya ilmiah mahasiswa berdasarkan judul, kata kunci, nama penulis, jurusan dan tahun terbit.

program ini dapat melakukan pencarian informasi koleksi karya ilmiah mahasiswa berdasarkan judul, kata kunci, nama penulis, jurusan dan tahun terbit.
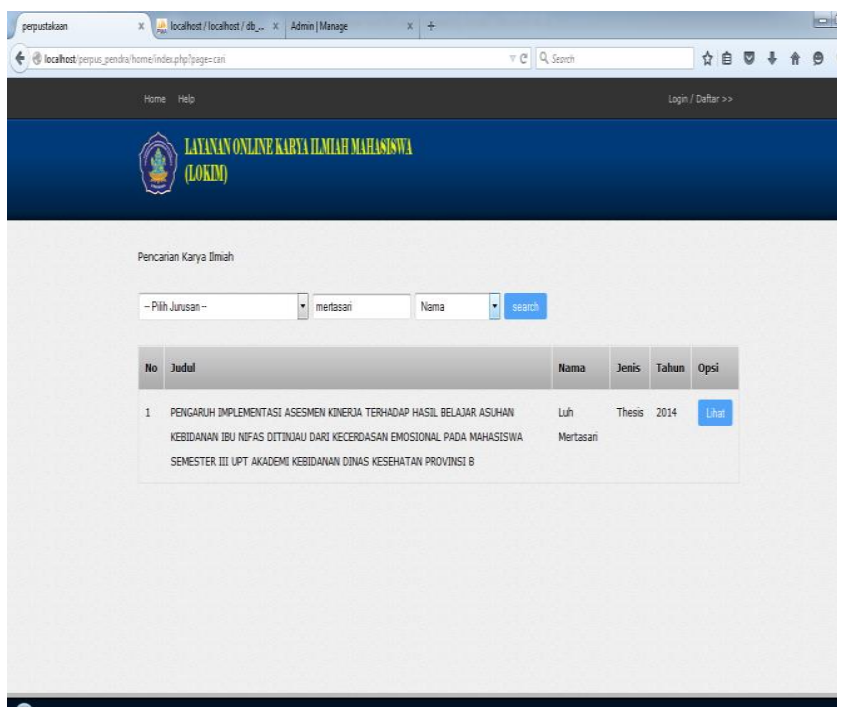

Gambar 7. Pencarian berdasarkan penulis Jurnal Sains dan Teknologi|709 
Pada ikon ini menyediakan pencarian koleksi karya ilmiah mahasiswa berdasarkan judul koleksi yang diinginkan atau kata kuncinya saja. Pada ikon ini, diketik penulis karya ilmiah mahasiswa

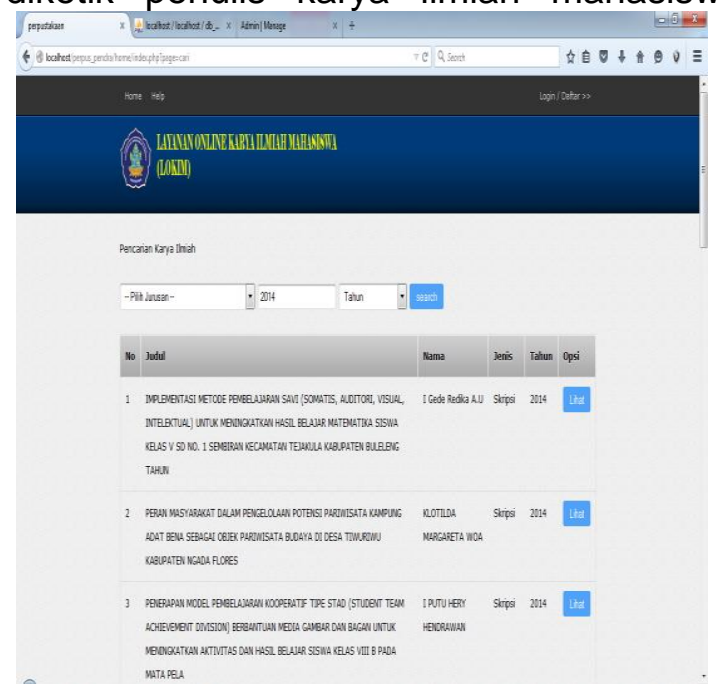

Gambar 8.Pencarian berdasarkan tahun terbit

Pada modul ini, pengguna dapat mengetik tahun terbit karya ilmiah yang diinginkan sebagai contoh di atas tahun 2014. Setelah mengklik search maka akan ditampilkan semua judul karya ilmiah mahasiswa yang terbit tahun 2014. Pada modul ini ditampilkan hasil pencarian berdasarkan judul/kata kunci/penulis secara fullteks.

Program sistem informasi koleksi karya ilmiah mahasiswa berbasis web telah diuji melalui beberapa pola pengujian. Uji yang diinginkan. Kemudian klik search maka akan ditampilkan data bibliografi seperti : judul nama penulis, tahun terbit, jenis karya ilmiah dan opsi.

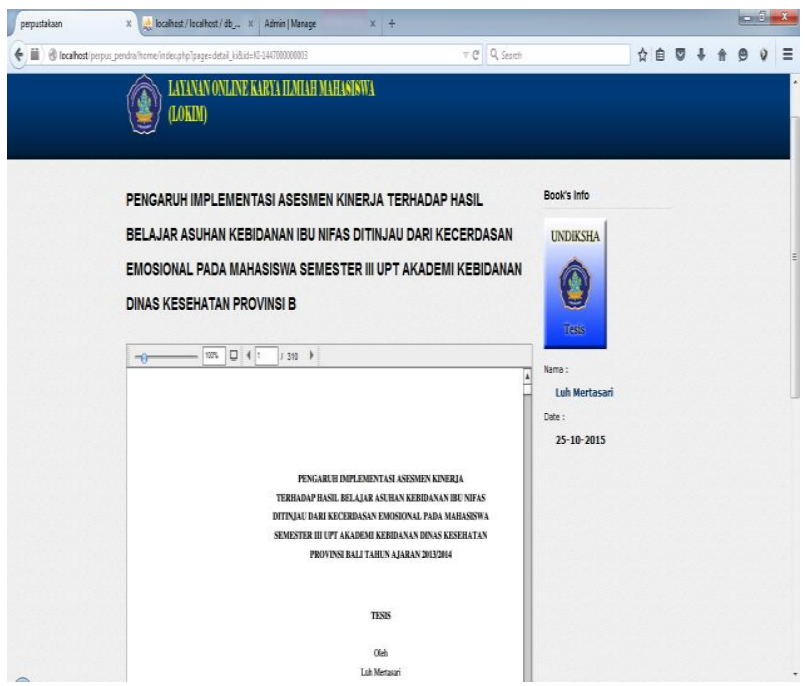

Gambar 9. Tampilan Fullteks

kelayakan oleh seorang pakar teknologi informasi, uji keterpakaian dilakukan oleh 35 orang pengguna (mahasiswa) yang terdiri dari 5 mahasiswa pasca sarjana, 5 mahasiswa fakultas ilmu pendidikan, 5 mahasiswa fakultas bahasa dan seni, 5 mahasiswa fakultas matematika dan ilmu pengetahuan alam, 5 mahasiswa fakultas ilmu sosial, 5 mahasiswa fakultas ekonomi dan bisnis dan 5 mahasiswa fakultas olahraga dan kesehatan. Hasil ujicoba terlihat pada table 1. 
Tabel 1. Hasil Penilaian oleh Pakar Teknologi Informasi

\begin{tabular}{|c|c|c|c|}
\hline No & Indikator & Deskriptor & Kualifikasi \\
\hline 1. & $\begin{array}{l}\text { Kebenaran } \\
\text { (Correctness) }\end{array}$ & $\begin{array}{l}\text { Kemampuan program dalam } \\
\text { mengerjakan tugasnya sesuai } \\
\text { dengan permintaan dan spesifikasi }\end{array}$ & $\begin{array}{l}\text { Baik, sudah sesuai } \\
\text { dengan spesifikasinya }\end{array}$ \\
\hline 2. & $\begin{array}{l}\text { Ketegaran } \\
\text { (Robustness) }\end{array}$ & $\begin{array}{l}\text { Kemampuan program untuk } \\
\text { mengantisipasi kondisi abnormal } \\
\text { dalam menjalankan fungsinya }\end{array}$ & $\begin{array}{l}\text { Cukup Memadai, } \\
\text { program sudah } \\
\text { diantisipasi agar mampu } \\
\text { menjalankan fungsinya } \\
\text { pada kondisi abnormal. }\end{array}$ \\
\hline 3. & $\begin{array}{l}\text { Keterluasan } \\
\text { (Extendibility) }\end{array}$ & $\begin{array}{l}\text { kemudahan untuk mengadaptasikan } \\
\text { program bila terjadi perubahan } \\
\text { spesifikasi }\end{array}$ & $\begin{array}{l}\text { Baik, dengan mudah } \\
\text { dilakukan perubahan } \\
\text { spesifikasi pada }\end{array}$ \\
\hline 4. & $\begin{array}{l}\text { Keterpakaian } \\
\text { ulang } \\
\text { (Reusability) }\end{array}$ & $\begin{array}{l}\text { Keberadaan program untuk bisa } \\
\text { dipergunakan } \\
\text { sebagian atau seluruhnyali } \\
\text { aplikasi lain }\end{array}$ & $\begin{array}{l}\text { Cukup memadai, dapat } \\
\text { dipergunakan untuk } \\
\text { sistem operasi baik linux } \\
\text { maupun windows. }\end{array}$ \\
\hline 5. & $\begin{array}{l}\text { Efisiensi atau } \\
\text { Kinerja }\end{array}$ & Efisiensi terhadap sumber daya & $\begin{array}{l}\text { Baik, hanya saja dengan } \\
\text { digunakan format swf } \\
\text { diperlukan spesifikasi } \\
\text { server yang bagus. }\end{array}$ \\
\hline 6. & $\begin{array}{l}\text { Portabilitas } \\
\text { (Portability) }\end{array}$ & $\begin{array}{l}\text { Kemudahan program ditransfer ke } \\
\text { perangkat keras yang berbeda }\end{array}$ & $\begin{array}{l}\text { Baik, dapat dengan } \\
\text { mudah ditransfer ke } \\
\text { hardware yang berbeda. }\end{array}$ \\
\hline 7. & Verifikasi & $\begin{array}{l}\text { Kemudahan untuk menelusuri } \\
\text { kegagalan program dan validasi }\end{array}$ & $\begin{array}{l}\text { Baik, program ini mudah } \\
\text { dilakukan perbaikan. }\end{array}$ \\
\hline 8. & $\begin{array}{l}\text { Integritas } \\
\text { (Integrity) }\end{array}$ & $\begin{array}{l}\text { Kemampuan program memproteksi } \\
\text { diri dari penggunaan dan modifikasi } \\
\text { illegal }\end{array}$ & $\begin{array}{l}\text { Cukup memadai, } \\
\text { program ini sudah } \\
\text { diproteksi dari } \\
\text { penggunaan illegal. }\end{array}$ \\
\hline 9. & $\begin{array}{l}\text { Modularitas } \\
\text { (Modularity) }\end{array}$ & $\begin{array}{l}\text { Pengaturan program dalam modul- } \\
\text { modul }\end{array}$ & $\begin{array}{l}\text { Baik, pengaturan } \\
\text { program dalam modul- } \\
\text { modul sudah sesuai }\end{array}$ \\
\hline 10. & $\begin{array}{l}\text { Keterbacaan } \\
\text { (Readness) }\end{array}$ & $\begin{array}{l}\text { Keterbacaan program oleh orang } \\
\text { lain selain programmer }\end{array}$ & $\begin{array}{l}\text { Baik, program ini bisa } \\
\text { dipahami oleh orang lain } \\
\text { selain programmer. }\end{array}$ \\
\hline
\end{tabular}

Berdasarkan penilaian oleh pakar teknologi informasi bahwa indikator penilaian meliputi kebenaran, keterluasan, efesiensi, portabilitas, verifikasi, 
modularitas dan keterbacaan mendapatkan kualifikasi baik, sedangkan ketegaran, keterpakaian ulang dan integritas mendapatkan kualifikasi cukup memadai yang perlu ditingkatkan lagi. Secara umum dari hasil penilaian tersebut dapat dikatakan program tersebut sudah baik artinya sudah cukup layak untuk digunakan oleh pengguna sebagai sistem informasi koleksi karya ilmiah mahasiswa yang berbasis web.

Tabel 2 Hasil Penilaian oleh Pengguna (Mahasiswa)

No Indikator Deskriptor Kualifikasi

1. Kinerja

2. Kemudahan pemakaian

3. Keramahan

4. Kebergunaan

Efektifitas layanan yang
diberikan perangkat lunak
sesuai dengan permintaan
dan spesifikasi

Tingkat pemakaian kemudahan perangkat lunak pengoperasian keramahan perangkat lunak untuk memberi petunjuk pada pengguna

Kebermanfaatan

atau kebergunaan perangkat lunak bagi pengguna

\begin{abstract}
Baik, program ini sudah
sesuai dengan permintaan

dan spesifikasi, untuk dapat mengakses informasi koleksi karya ilmiah mahasiswa secara online dengan
\end{abstract} Baik, mudah dioperasikan dalam mengakses informasi koleksi karya ilmiah Sudah baik, ikon-ikon pada program ini, yang sudah jelas.

Sangat baik, program ini dapat mengakses informasi koleksi karya ilmiah mahasiswa secara online
Berdasarkan hasil penilaian oleh pengguna didapatkan bahwa kinerja, kemudahan pemakaian, keramahan, dan kebergunaan perangkat lunak ini memiliki kualifikasi baik berarti program ini sudah layak untuk digunakan oleh pengguna.

Sistem informasi koleksi karya ilmiah mahasiswa berbasis web telah diimplementasikan. Perangkat lunak sistem informasi karya ilmiah mahasiswa berbasis web yang sudah dikembangkan kemudian diintegrasikan dengan program bebas pustaka online yang ada di web UNDIKSHA dengan alamat http: www. Undiksha.ac.id. dan program sistem otomasi pengolahan koleksi karya ilmiah mahasiswa. Pengembangan sistem informasi koleksi karya ilmiah mahasiswa berbasis web ini bertujuan untuk dapat mengakses koleksi karya ilmiah mahasiswa dengan fulltext secara online sehingga pengguna memperoleh informasi yang diinginkan tanpa terbatas tempat dan waktu, dimana dan kapan saja bila terhubung dengan internet. Berdasarkan hasil dari beberapa pengujian yakni uji kelayakan oleh pakar teknologi informasi dan uji keterpakaian oleh mahasiswa sebagai pengguna, maka dapat diuraikan hasil ujicoba sebagai berikut: (1) Pengembangan sistem informasi koleksi karya ilmiah mahasiswa berbasis web 
sudah sesuai dengan spesifikasi yang telah ditentukan sebagai sistem informasi koleksi karya ilmiah mahasiswa berbasis web untuk dapat mengakses informasi koleksi karya ilmiah mahasiswa secara online dengan tampilan fulltext, (2)Sistem informasi koleksi karya ilmiah mahasiswa bisa diakses di internet sehingga pengguna dapat memperoleh informasi dimana dan kapan saja, tanpa terbatas ruang dan waktu apabila terhubung internet, (3)Perangkat lunak ini dapat dioperasikan dengan mudah, tidak terlalu teknis, sehingga tidak perlu dilakukan pelatihan yang khusus kepada pengguna, (4) Indikator penilaian dari program ini seperti : kebenaran, keterluasan,efesiensi, portabilitas, verifikasi, modularitas dan keterbacaan kinerja, kemudahan pemakaian, keramahan, dan kebergunaan mendapatkan kualifikasi baik, sedangkan ketegaran, keterpakaian ulang dan integritas yang dinilai oleh pakar teknologi informasi dengan kualifikasi cukup memadai yang perlu ditingkatkan lagi. Secara umum dari hasil penilaian tersebut dapat dikatakan program tersebut sudah baik artinya sudah cukup layak untuk digunakan oleh pengguna sebagai sistem informasi koleksi karya ilmiah mahasiswa yang berbasis web. (5) Secara umum, perangkat lunak ini sudah cukup layak untuk digunakan tapi ada beberapa hal yang perlu ditingkatkan seperti proteksi program dari pengguna dan modifikasi illegal perlu ditingkatkan. Diperlukan penyediaan server dengan kapasitas yang memadai agar dapat menampung data yang banyak karena program ini terintegrasi dengan bebas pustaka online dan digunakannya format swf untuk antisipasi penjiplakan.

\section{SIMPULAN}

Pengembangan sistem informasi koleksi karya ilmiah mahasiswa berbasis web sudah diimplementasikan dan diintegrasikan dengan program bebas pustaka online yang sudah dihasilkan pada penelitian sebelumnya. Pengembangan ini bertujuan untuk dapat mengakses koleksi karya ilmiah mahasiswa secara online dengan tampilan file koleksi fulltext sehingga pengguna memperoleh informasi yang diinginkan tanpa terbatas tempat dan waktu, dimana dan kapan saja bila terhubung dengan internet.

Berdasarkan hasil dari beberapa pengujian yakni uji kelayakan oleh pakar teknologi informasi dan uji keterpakaian oleh mahasiswa sebagai pengguna, maka dapat diuraikan hasil ujicoba sebagai berikut: 1) Pengembangan sistem informasi koleksi karya ilmiah mahasiswa berbasis web sudah sesuai dengan spesifikasi yang telah ditentukan sebagai sistem informasi berbasis web untuk dapat mengakses informasi koleksi karya ilmiah mahasiswa secara online dengan tampilan fulltext. 2) Perangkat lunak ini dapat dioperasikan dengan mudah, tidak terlalu teknis, sehingga tidak perlu dilakukan pelatihan yang khusus kepada pengguna. 3)Indikator penilaian dari program ini seperti: kebenaran, keterluasan,efesiensi, portabilitas, verifikasi, modularitas, keterbacaan kinerja, kemudahan pemakaian, keramahan, dan kebergunaan mendapatkan kualifikasi baik, sedangkan ketegaran, keterpakaian ulang dan integritas mendapatkan kualifikasi cukup memadai yang perlu ditingkatkan lagi. 3) Secara umum dari hasil penilaian tersebut dapat dikatakan program tersebut sudah baik artinya sudah cukup layak untuk digunakan oleh pengguna sebagai sistem informasi koleksi karya ilmiah mahasiswa 
yang berbasis web. 4) Secara umum, perangkat lunak ini sudah cukup layak untuk digunakan tapi ada beberapa hal yang perlu ditingkatkan seperti proteksi program dari pengguna dan modifikasi illegal perlu ditingkatkan, diperlukan penyediaan server dengan kapasitas yang memadai agar dapat menampung data yang banyak karena program ini terintegrasi dengan bebas pustaka online dan digunakannya format swf untuk antisipasi penjiplakan.

Sistem informasi koleksi karya ilmiah mahasiswa berbasis web ini sudah dikembangkan dan sudah diujicoba secara terbatas. Hasilnya menunjukkan kebermanfaatannya untuk mengakses koleksi karya ilmiah mahasiswa secara online dengan tampilan file koleksi fulltext sehingga pengguna memperoleh informasi yang diinginkan tanpa terbatas tempat dan waktu, dimana dan kapan saja bila terhubung dengan internet. Oleh karena itu kepada para pengguna perpustakaan Undiksha disarankan untuk memanfaatkan portal web tersebut untuk memudahkan melakukan penelusuran informasi tentang koleksi karya ilmiah mahasiswa Undiksha.

Program ini masih terbuka untuk dikembangkan baik secara teknis maupun ide. Terutama bagi pengelola perpustakaan Undiksha disarankan untuk mengembangkan program ini demi upaya peningkatan kualitas layanan perpustakaan dan pengelolaan perpustakaan secara professional sesuai perkembangan teknologi informasi.

\section{UCAPAN TERIMAKASIH}

Penghargaan dan terima kasih diberikan kepada Direktur Pembinaan Penelitian dan Pengabdian Kepada Masyarakat (Ditbinlitabmas) Direktorat Jenderal Pendidikan Tinggi Depdiknas yang telah memberikan bantuan dana sehingga penelitian ini dapat berjalan sesuai rencana dan keinginan peneliti. Penelitian ini dibiayai dari dana DIPA Universitas Pendidikan Ganesha dengan SPK Nomor :175 /UN48.14/PL/2015 Tanggal 16 Februari 2015.

\section{DAFTAR PUSTAKA}

Azizah, et all. 2011. Pengembangan ElibISIS (Electronic Library berbasis data CDS/ISIS). Jurnal Pustakawan Indonesia. Vol. 11, No. 2 (38)

Candiasa, I Made, et all. 2012. Pemerataan dan Peningkatan Mutu Pendidikan Melalui Komunitas Guru Online. Laporan Penelitian DIPA. Lembaga Penelitian Undiksha

Corbin, J.1985. Managing The Library Automation Project. Canada:Oryx Press.

Hamad, I. 2010.Transformasi Kultural Menuju Masyarakat Informasi. Jurnal dialog Kebijakan Publik. 10(35)

Lutriani. 2011. Digital Library : Penerapan Teknologi Informasi (TI) Di Perpustakaan. Media Pustakawan. Vol. 18 No. 3 \& 4(38)

Pendra Mahardika, I Made, Ni Ketut Rai Yuli, Ni Kadek Etik Suparmini. 2014. Pengembangan Program Layanan Bebas Pustaka Online Untuk Meningkatkan Efektivitas Dan Efesiensi Layanan Perpustakaan (Studi Kasus : Universitas Pendidikan Ganesha). Jurnal Sains \& Teknologi. Vol 3. No.1(344)

Rahayu, Sri. 2011. Optimalisasi Fitur Pengindeksan Winisis Untuk Ketepatan dan Kecepatan Layanan Penelusuran Pustaka Kelabu. Jurnal Pustakawan Indonesia . Vol. 11 No.2(14) 
Riyadi, Agung. 2011. "Sistem Informasi". Tersedia pada http://agungsr.staff.gunadarma.ac.id /Downloads/files/3412/Konsep+SI. pdf (diakses tanggal 5 September 2014)

Rowley.1980. Computers Libraries. London:Clive Bingley

Setemen, Komang, Luh Joni Erawati, Ni Wayan Marti. 2012. Pengembangan Aplikasi Pengelolaan Karya IImiah Mahasiswa dan Dosen Berbasis
Teknologi Web. Jurnal Sains\&Teknologi. Vol. 1 No.2 (107) Sugiarti, Yuni .2011. Peranan Teknologi Internet dalam Membangun Pendidikan Karakter Anak. Jurnal Teknodik. Vol. XXV No.2(145)

UU RI 43 Tahun 2007.Jakarta: Perpustakaan Nasional RI

Welnadi.2010.Dinamika Informasi dan Hukum di Dunia Maya.Jurnal Dialog Kebijaka Publik.10(8). 